18. Farenii, I. A. (2008). Kooperatyvnyi rukh u Naddniprianskii Ukraini v druhii polovyni XIX - na pochatku XX st. [The cooperative movement in the Dnieper Ukraine in the second half of the XIX-early XX c.]. Cherkasy: Vidlunnia-Plius, 2008.

19. Fromett, B. (1914). Vojna i kulturno-obshestvennye zadachi kooperacii [War and the cultural and social tasks of cooperation.]. Vestnik kooperacii, 6-7.

УДК 323.1:81’246.3(477.52/.6)

\title{
МОВНА СТРУКТУРА НАСЕЛЕННЯ ПІВДЕННОЇ УКРАЇНИ (ЗА МАТЕРІАЛАМИ ВСЕСОЮЗНОГО ПЕРЕПИСУ НАСЕЛЕННЯ 1926 РОКУ)
}

\section{Малярчук Наталя}

Автором проаналізовано склад населення Південної України за рідною мовою, розглянуто особливості мовної структури по окремих округах, а також міських та сільських поселеннях регіону, здійснено порівняльний аналіз етнічної та мовної структур населення, визначено рівень та характер асимілячійних процесів в регіоні та по УСРР загалом.

За підсумками дослідження автор дійшов висновків, що у 1926 р. абсолютна більшість населення Південної України вважала своєю рідною мовою українську. Аналіз мовної структури населення окремих округ Південної України показав, щзо у більшості з них, окрім Одеської, переважало україномовне населення. Російська, яку визнали рідною менше чверті населення, була другою за демографічною потужністю мовою регіону. Проте вона мала більшу комунікаційну потужність $i$, як наслідок, більший асиміляційний потенціал, ніж украӥнська. Мови інших народів, щзо проживали на території регіону, загалом посідали незначне місце у його мовному середовищі.

Порівняльний аналіз етнічної та мовної структури населення Південної Украӥни показав, щуо украӥнці, попри свою чисельну перевагу, здійснювали дуже незначний асиміляційний вплив на інші етнічні спільноти регіону. Більще того, вони самі зазнавали асиміляції з боку російської етнічної меншини. Це дозволило зробити висновок про деформованість мовної ситуації у регіоні, а також про неприродний та асиметричний характер асиміляційних проиесів. Російський асиміляційний вплив найбільш потужно проявлявся у великих містах - адміністративних, економічних та культурних иентрах Півдня України. У невеликих містах та сільських поселеннях процес російської асиміляиії відбувався повільніше, і для населення більшості з них рідною була українська мова.

Автором зроблено висновок, щзо хоча в иілому русифікація на Півдні України у 1926 р. ще не набула загрозливого характеру, і для абсолютної більшості населення рідною була мова власної національності, проте асиміляційні процеси в регіоні відбувалися більш інтенсивно, ніж загалом по УСРР.

Ключові слова: росіяни, україниі, Всесоюзний перепис населення 1926 р., Південна Україна, російська мова, украӥнська мова. 
Необхідність та важливість усебічного дослідження мовної ситуації в Україні на різних історичних етапах обумовлено тим, що мовне питання у наш час перетворилося на важливий чинник як внутрішньої, так і зовнішньої політики, активно використовується для різноманітних маніпуляцій з громадською свідомістю. Це особливо актуально для регіонів, які зазнали значної русифікації, зокрема Південної України. Дослідження мовної структури населення регіону в різні періоди вітчизняної історії дозволить простежити динаміку змін, яких вона зазнавала протягом часу, та системно проаналізувати їх. Значну зацікавленість викликає початок другої половини 20-х р. ХХ ст., тобто час ще до початку сталінської модернізації, яка дала поштовх значним міграційним процесам в СРСР, що суттєво вплинули на етнічну та мовну структуру населення окремих регіонів. Важливим джерелом дослідження зазначеного питання у цей період $є$ Всесоюзний перепис населення 1926 р.

Актуальність статті обумовлюється й тим, що більшість вітчизняних дослідників користувалися даними перепису 1926 р. для вивчення соціальної й етнічної структури населення УСРР, а також іï окремих регіонів $[2 ; 4 ; 7 ; 8 ; 9 ; 12]$, проте його інформаційні можливості щодо висвітлення мовних процесів використані не в повному обсязі $[6 ; 10,99]$.

Мета статті: дослідити особливості мовної структури населення Південної України на основі аналізу матеріалів Всесоюзного перепису населення 1926 р.

Географічними межами дослідження є територія Південної України, тобто сучасних Дніпропетровської, Запорізької, Кіровоградської, Миколаївської, Одеської, Херсонської областей, яка в 1926 р. поділялася на 9 округ: Мелітопільську [Н. М.: назви округ у статті подаються відповідно до перепису], Запорізьку, Одеську, Миколаївську, Херсонську, Дніпропетровську, Зінов’ївську, Криворізьку, Першомайську. У географічні межі дослідження не увійшов Крим, оскільки на той час він не перебував у складі УСРР, а також Автономна Молдавська СРР, яка, хоча і входила до 1940 р. до складу УСРР, але не була повністю етнічною українською територією.

Джерельною базою дослідження є Всесоюзний перепис населення 1926 р. Серед п'ятнадцяти пунктів особового листка, який складали на кожного громадянина СРСР, п'ятим номером містився пункт «рідна мова». Згідно 3 настановою для рахівників, що здійснювали перепис, поняття «рідна мова» мало наступне визначення: «Рідною мовою визнається та, якою опитуваний найкраще володіє або якою зазвичай розмовляє» $[1,32]$. Дані щодо рідної мови жителів півдня УСРР були опубліковані у 13 томі зазначеного перепису, у табл. VI «Людність за національністю, рідною мовою та письменністю». Саме на них грунтуються усі підрахунки автора статті, таблиці та діаграми (відомостях щодо рідної мови насе- 
лення дев'яти південноукраїнських округ, а також їхніх міських та сільських поселень) [4, с. 12-33, 35-39, 247-256]. Дані щодо зазначених показників по УСРР взято з видання «Короткі підсумки перепису населення України. 12-17 грудня 1926 р. Національний і віковий склад, рідна мова та писемність населення» [11, 42-45].

Аналіз даних Всесоюзного перепису населення 1926 р. показав, що для абсолютної більшості - 68,2 \% (4 418621 ос.) населення Південної України рідною мовою була українська, тоді як російську визнав такою лише 21,1 \% (1 367544 ос.), ще 10,4 \% (676 162 ос.) назвали рідними інші мови, і 0,3 \% (21 298 ос.) мешканців регіону рідну мову не зазначили. Отже, за своєю демографічною потужністю українська мова більш ніж утричі перевищувала російську (див. діаграму 1).

Для порівняння зазначимо, що загалом по УСРР українська мова була рідною для 76,4 \% (22 160992 ос.) населення, російська - для 15,2 \% (4 421813 ос.), ще для 8 \% (2 304250 ос.) рідними були інші мови, а 0,4 \% (109 485 ос.) рідну мову не вказали (див. діаграму 2).

\section{Діаграма1}

Населення Південної України за рідною мовою

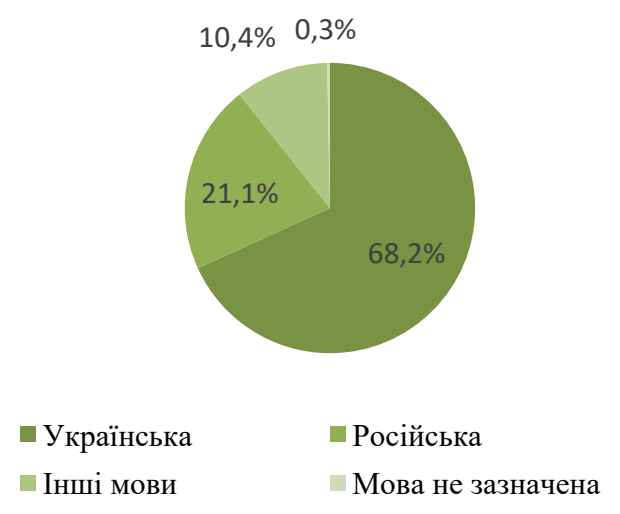

\section{Діаграма 2}

Населення УСРР

за рідною мовою

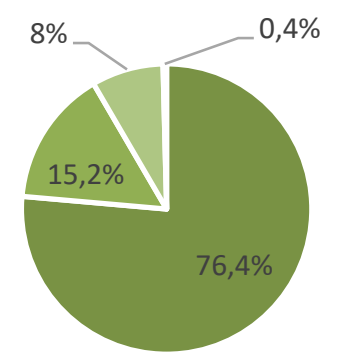

- Українська - Російська

- Інші мови $\square$ Не зазначена

Таким чином, питома вага російськомовного населення серед мешканців Південної України була майже в півтора раза більшою, ніж загалом по УСРР. Відрізнялося і співвідношення україномовного і російськомовного населення в межах регіону та загалом по республіці. Так, у Південній Україні частка україномовного населення утричі перевищувала частку російськомовного, тоді як загалом по УСРР - у п'ять разів. Зазначимо також, що на півдні було зосереджено $31 \%$ усього російськомовного населення УСРР.

Про деформованість мовної ситуації в регіоні свідчить розбіжність між рідною мовою та етнічною приналежністю частини населення. Так, у 1926 р. частка українців серед населення Південної України становила 73 \%, тоді як українську мову визнали рідною лише 68,2 \% від загалу. Натомість російську назвали 
рідною мовою 21,1\% населення, попри те, що частка росіян серед мешканців півдня України дорівнювала лише 13 \% [9, 230]. Була наявною диспропорція між питомою вагою представників інших національностей у етнічній структурі населення Південної України та часткою інших мов у його мовній структурі: $14 \%$ та 10,4 \% відповідно (див. діаграму 3).

Діаграма 3

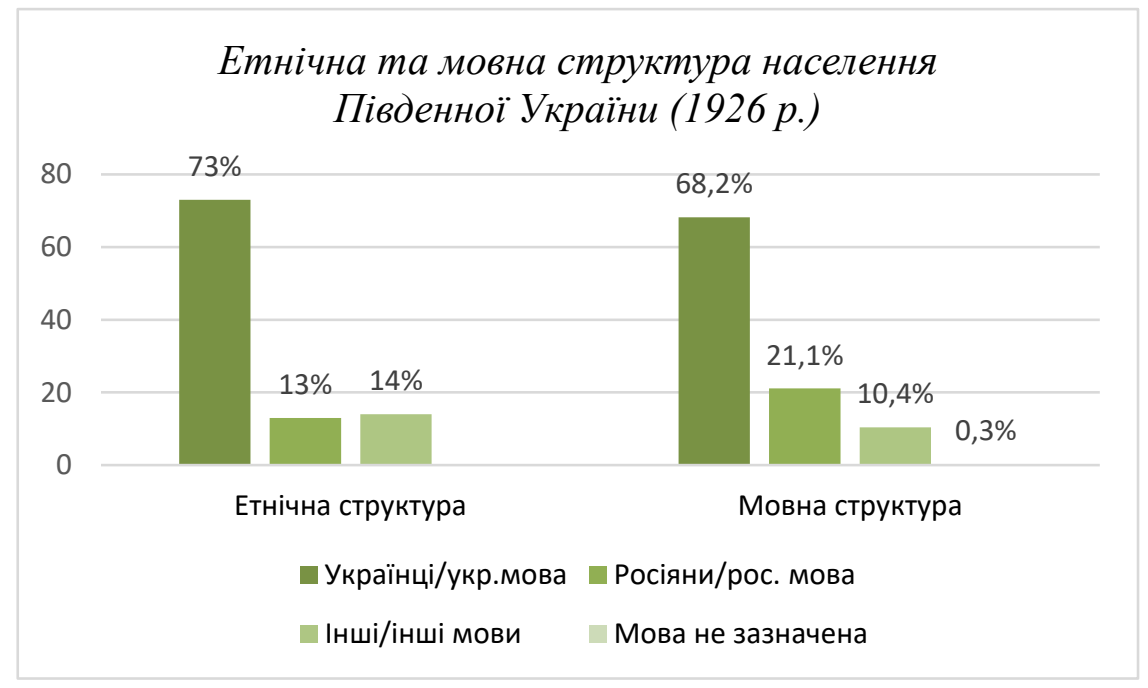

Питома вага тих, хто визнав російську мову рідною, у півтора раза перевищувала частку етнічних росіян, що мешкали в Південній Україні. Зауважимо, що, серед російськомовних, етнічні росіяни становили лише $60 \%$ (820 257 ос.), тоді як 24 \% (325 135 ос.) - українці, 12 \% (160 396 ос.) - євреї, а ще 4 \% (61 756 ос.) представники інших етнічних груп. Щодо населення з українською рідною мовою, то воно на 92,7 \% (4 381608 ос.) складалося з українців, відсоток представників інших національностей був незначний $-7,3 \%$. Отже російська спільнота, яка за кількісними показниками поступалася українцям і фактично була етнічною меншиною, хоча й найчисельнішою, здійснювала значний асиміляційний вплив на українське та інонаціональне населення Південної України. Разом 3 тим іiі представники демонстрували високу мовну стійкість, оскільки $98 \%$ (820 257 ос.) росіян регіону визнали рідною мову своєї національності, й лише 1,6 \% (13 959 ос.) - українську та $0,1 \%$ (693 ос.) - інші мови (0,3 \% рідну мову не зазначили).

Відповідно, українці мали меншу мовну стійкість, ніж росіяни: українську визнали рідною мовою 92,7 \% (4 381608 ос.) етнічних українців, 7 \% (325 135 ос.) російську і 0,1 \% (4 180 ос.) - мову інонаціонального населення Південної України $(0,3 \%$ рідну мову не зазначили). Отже, попри кількісне домінування в регіоні українців, їхній асиміляційний вплив на представників етнічних меншин був незначний, більше того, вони самі були об’єктом асиміляції з боку російської етнічної меншини. 
Таблиця 1

Населення Південної України за рідною мовою по округах (\%)

\begin{tabular}{|c|l|c|c|c|c|}
\hline \multirow{2}{*}{ № } & \multirow{2}{*}{ Округа } & \multicolumn{4}{|c|}{ Рідна мова } \\
\cline { 3 - 6 } & & українська & російська & інші & не зазначена \\
\hline 1 & Першомайська & 86 & 4 & 9,8 & 0,2 \\
\hline 2 & Криворізька & 85,4 & 9,3 & 5 & 0,3 \\
\hline 3 & Зінов'ӥвська & 79,4 & 14 & 6,3 & 0,3 \\
\hline 4 & Запорізька & 78 & 15,4 & 6,3 & 0,3 \\
\hline 5 & Дніпропетровська & 77,3 & 18 & 4,3 & 0,4 \\
\hline 6 & Херсонська & 68,7 & 22 & 9 & 0,3 \\
\hline 7 & Мелітопільська & 52 & 33 & 14,7 & 0,3 \\
\hline 8 & Миколаївська & 51,8 & 33 & 15 & 0,2 \\
\hline 9 & Одеська & 35,6 & 39,1 & 25 & 0,3 \\
\hline & Разом & 68,2 & 21,1 & 10,4 & 0,3 \\
\hline
\end{tabular}

Як видно з таблиці 1, у всіх округах Південної України, крім Одеської, абсолютна більшість населення назвала рідною мовою українську. Так, у Першомайській окрузі цей показник склав $86 \%$ від загалу, у Криворізькій - 85,4 \%, Зінов'ївській - 79,4 \%, Запорізькій - 78 \%, Дніпропетровській - 77,3 \%, Херсонській - 68,7\%, Мелітопільській - $52 \%$, Миколаївській - 51,8 \%. І лише в Одеській окрузі відносну більшість - 39,1 \% склало населення з рідною мовою російською, причому етнічні росіяни серед російськомовного населення округи становили лише $59 \%$, а $41 \%$ - представники інших національностей (у тому числі $16 \%$ становили українці, $5 \%$ - євреї).

Щодо мов інших народів, то вони посідали незначне місце в мовному середовищі Південної України. Лише 10,4 \% населення не визнали рідною українську або російську, а назвали такою іншу мову. Найбільш помітною частка іншомовного населення - 25 \% від загалу - була в Одеській окрузі, яка відрізнялася від інших найбільш строкатим етнічним складом населення.

Переважна більшість україномовного населення зосереджувалася у сільській місцевості Південної України - $92 \%$ (4 075087 ос.), тоді як у містах мешкало лише 8 \% (343 534 ос.) від україномовного загалу. Більшість іншомовного населення так само мешкала в селі - 66 \% (445 205 ос.), тоді як 34 \% (230 957 ос.) у містах. Щодо російськомовної спільноти, то ііі розподіл між містом і селом був більш збалансованим. Абсолютна більшість російськомовного населення була сконцентрована у містах - $55 \%$ (747 823 ос.), тоді як на села припадало $45 \%$ (619 721 ос.) від російськомовного загалу.

Аналіз мовної структури міського населення Південної України показав, що питома вага тих, хто визнав рідною мовою російську, становила - $56 \%$ (747 823 ос.), українську - 26\% (343 534 ос.), інші мови - $17 \%$ (230 957 ос.), $1 \%$ (7 034 ос.) опитаних не зазначив рідну мову взагалі (див. діаграму 4). Заува- 
жимо, що загалом серед міського населення УСРР російськомовні хоча й становили більшість, проте не абсолютну, а відносну. Так, їхня частка становила $44 \%$ (2 386638 ос.), тоді як частка україномовних - 36\% (1930620ос.), іншомовних - $19 \%$ (1 004103 ос.), а $1 \%$ (37 879 ос.) опитаних не зазначив рідну мову взагалі (див. діаграму 5).

\section{Діаграма 4}

Міське населення Південної

Украӥни за рідною мовою

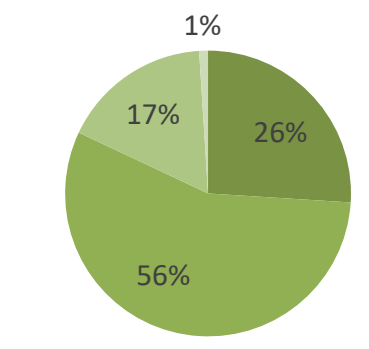

Українська Російська

$\square$ Інші мови $\quad$ Не зазначена

Діаграма 5

Міське населення УСРР за рідною мовою

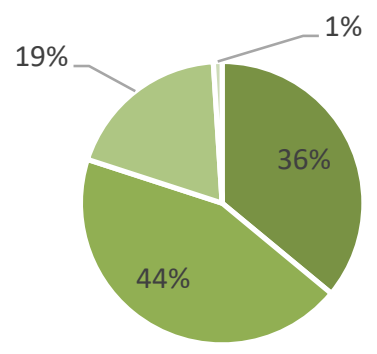

- Українська " Російська

- Інші мови $\quad$ Не зазначена

Міста Південної України були осередками російської мовної асиміляції, про що свідчить значна розбіжність між мовою та національною приналежністю їхніх мешканців (див. діаграму 6).

Діаграма 6

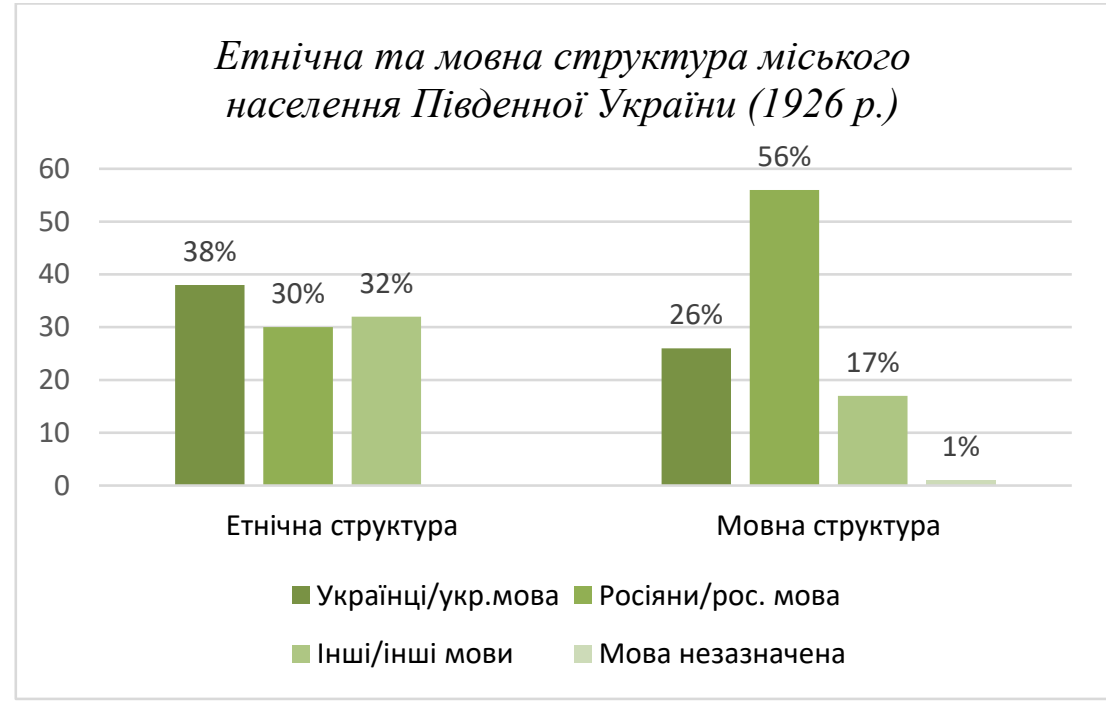

Так, частка українців серед міського населення Південної України становила у 1926 р. 38 \%, тоді як українську мову визнали рідною лише $26 \%$ загалу. Натомість російську назвали рідною мовою $56 \%$ населення, попри те, що частка росіян серед міського населення дорівнювала 30 \%. Питома вага інонаціонального населення - $32 \%$ - майже удвічі перевищувала частку іншомовних мешканців міст - $17 \%$ [9, 231]. 
Таблиця 2

Міське населення Південної України за рідною мовою по округах (\%)

\begin{tabular}{|c|l|c|c|c|c|}
\hline \multirow{2}{*}{ № } & \multirow{2}{*}{ Округа } & \multicolumn{4}{|c|}{ Рідна мова } \\
\cline { 3 - 6 } & & українська & російська & інші & не зазначена \\
\hline 1 & Криворізька & 62 & 30 & 8 & 1 \\
\hline 2 & Зінов’ївська & 48 & 35 & 16 & 1 \\
\hline 3 & Першомайська & 45 & 14 & 40 & 1 \\
\hline 4 & Запорізька & 39 & 48 & 12 & 1 \\
\hline 5 & Дніпропетровська & 29 & 57 & 13 & 1 \\
\hline 6 & Херсонська & 26 & 59 & 14 & 1 \\
\hline 7 & Мелітопільська & 17 & 72 & 10 & 1 \\
\hline 8 & Миколаївська & 17 & 70 & 13 & 1 \\
\hline 9 & Одеська & 11 & 65 & 23,7 & 0,3 \\
\hline & Разом & 26 & 56 & 17 & 1 \\
\hline
\end{tabular}

Із таблиці 2 видно, що лише в одній із дев'яти округ Південної України Криворізькій - абсолютна більшість мешканців міських поселень - $62 \%$ - визнали рідною українську мову, тоді як російську - 30\%, а інші мови - 8 \% (1\% рідну мову не зазначив). У двох округах, Зінов’ївській та Першомайській, населення з рідною українською мовою становило відносну більшість - $48 \%$ та $45 \%$ відповідно. Російську назвали рідною $35 \%$ та $14 \%$ населення цих округ, тоді як $16 \%$ і $40 \%$ відповідно визнали рідними інші мови (по $1 \%$ населення рідну мову не зазначило). У решті округ більшість склало населення з рідною російською мовою. У Запорізькій області ця більшість була відносною - 48 \% від загалу, а інших п'яти - абсолютна. Так, у Дніпропетровській області цей показник склав $57 \%$, Херсонській - 59 \%, Одеській - 65 \%, Миколаївській - 70 \%, Мелітопільській $-72 \%$.

У великих містах (населення яких перевищувало 50 тис. осіб) кількісне домінування населення з рідною російською мовою було ще більш яскраво виражене. Згідно з Всесоюзним переписом населення, у 1926 р. на півдні Україні було шість таких міст: Одеса, Дніпропетровське (сучасн. Дніпро), Миколаїв, Зінов'ївське (сучасн. Кропивницький), Херсон, Запоріжжя. 65 \% населення цих міст назвали рідною російську мову, і лише $15,5 \%$ - українську. У таких містах, як Миколаїв, Херсон, Одеса, Дніпропетровськ україномовне населення не становило й чверті населення, тоді як частка російськомовного дорівнювала $78 \%$, 66,4 \%, 66,1 \% и 64 \% відповідно (див. таблицю 3). 
Таблиця 3

Населення найбільших міст Південної України за рідною мовою (\%)

\begin{tabular}{|c|l|c|c|c|c|}
\hline \multirow{2}{*}{ № } & \multirow{2}{*}{ Місто } & \multicolumn{4}{c|}{ Рідна мова } \\
\cline { 3 - 6 } & & російська & українська & інші & не зазначена \\
\hline 1 & Миколаїв & 78 & 10 & 11 & 1 \\
\hline 2 & Херсон & 66,4 & 16,3 & 16,2 & 1,2 \\
\hline 3 & Одеса & 66,1 & 10,1 & 23,5 & 0.3 \\
\hline 4 & Дніпропетровськ & 64 & 20 & 15 & 1 \\
\hline 5 & Зінов'ївське & 54 & 26 & 19 & 1 \\
\hline 6 & Запоріжжя & 52 & 34 & 13,5 & 0,5 \\
\hline & Разом & 65 & 15,5 & 19 & 0,5 \\
\hline
\end{tabular}

Щодо менших міст, то більшість їхнього населення - $50 \%$ - визнала рідною українську мову, тоді як російську - 35\%, інші мови - 14 \% (1 \% рідну мову не зазначив) (див. таблицю 4). Лише в містах двох округ - Мелітопільської і Херсонської - переважало населення з рідною мовою російською. Їхня питома вага становила відповідно 71,7 \% і 46 \% від загалу. Найменшим відсоток російськомовних був у містах Зінов'ївської округи - 12,1\%. Щодо україномовних городян, то найбільш значною їхня частка була у Запорізькій окрузі - 77 \% від загалу, а найменшою - в Мелітопільській - 17 \% від загалу.

Таблиця 4

\section{Рідна мова мешканців міст Південної України 3 населенням не більш ніж 50 тис. осіб (\%)}

\begin{tabular}{|l|l|c|c|c|c|}
\hline \multirow{2}{*}{ № } & \multirow{2}{*}{ Округа } & \multicolumn{4}{|c|}{ Рідна мова } \\
\cline { 3 - 6 } & & українська & російська & інші & не зазначена \\
\hline 1 & Запорізька & 77 & 16 & 6,3 & 0,7 \\
\hline 2 & Зінов'ївська & 74,2 & 12,1 & 13,3 & 0,4 \\
\hline 3 & Криворізька & 61,5 & 30 & 8 & 0,5 \\
\hline 4 & Дніпропетровська & 51 & 40 & 8 & 1 \\
\hline 5 & Першомайська & 45 & 14 & 40 & 1 \\
\hline 6 & Херсонська & 44 & 46 & 9 & 1 \\
\hline 7 & Миколаївська & 42 & 39 & 18 & 1 \\
\hline 8 & Одеська & 31,3 & 32,3 & 36 & 0,4 \\
\hline 9 & Мелітопільська & 17 & 71,7 & 10,9 & 0,4 \\
\hline & Разом & 50 & 35 & 14 & 1 \\
\hline
\end{tabular}

У Південній Україні, як і по республіці загалом, українська мова була значно більш поширена у селах, ніж у містах.

Так серед сільських жителів регіону визнали рідною мовою українську 79 \% (4 075087 ос.), російську - 12 \% (619 721 ос.), інші мови - 8,6 \% (445 205 ос.), не зазначили рідну мову - 0,4 \% (14 264 ос.) від загалу. Але навіть на селі частка україномовного населення у Південній Україні була меншою ніж загалом по УСРР, і відповідно більшою була питома вага російськомовного населення (див. 
діаграми 7 та 8). Так, україномовні становили 85,6 \% (20 230372 ос.) сільського населення республіки, російськомовні - 8,6 \% (2 035175 ос.), іншомовні - 5,5\% (1 300147 ос.), не зазначили рідну мову 0,4 \% (71 606 ос.) від загалу.

Мовна ситуація на селі не була настільки деформованою, як у міських поселеннях Південної України, оскільки розбіжність між рідною мовою та етнічною приналежністю частини населення була значно меншою (див. діаграму 9).

\section{Діаграма 7}

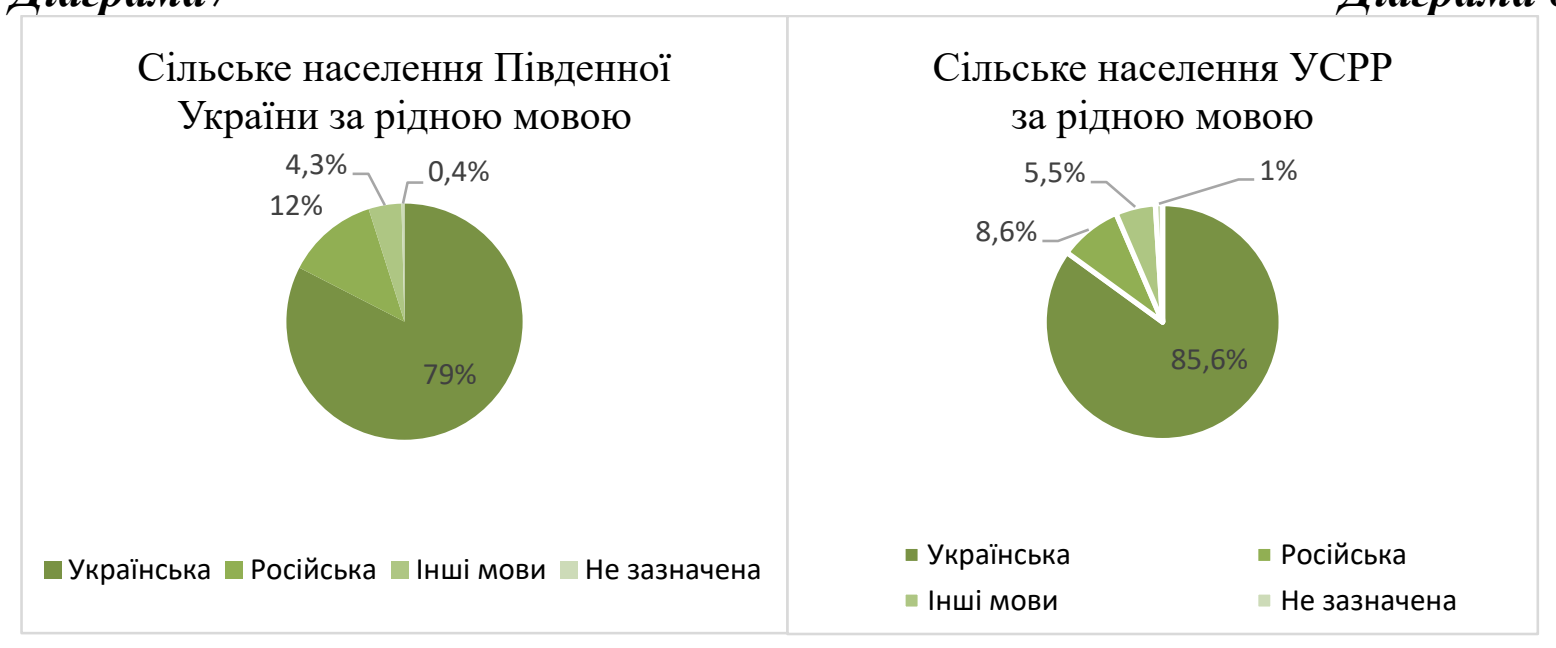

Діаграма 9

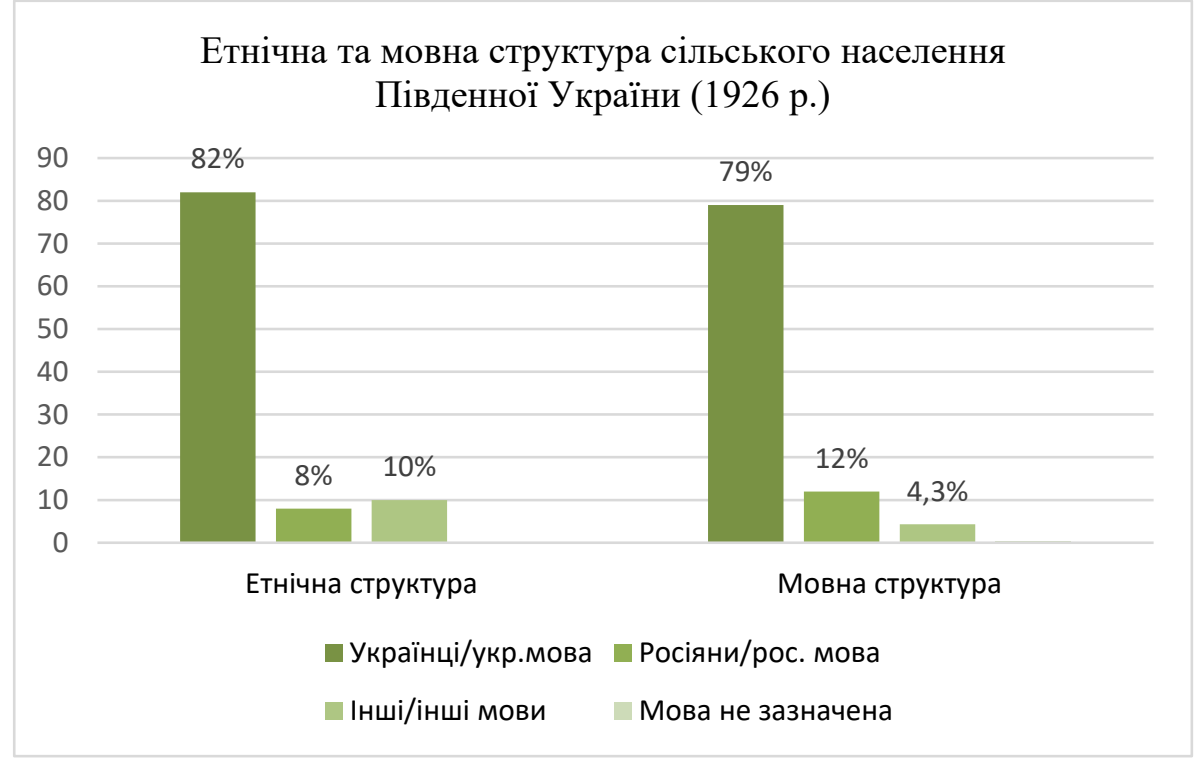

Так, частка українців серед сільського населення Східної України становила $82 \%$, а українську мову визнали рідною $79 \%$ загалу. Натомість російську назвали рідною мовою $12 \%$ населення, попри те, що частка росіян серед сільського населення дорівнювала 8 \%. Питома вага інонаціонального населення - $10 \%-$ перевищувала частку іншомовних мешканців сіл - 4,3\% [9, 233]. Не зазначили рідну мову $0,4 \%$ сільських жителів.

В усіх округах Південної України абсолютна більшість сільського населення визнала рідною українську мову (див. таблицю 5). Найвищим цей показник 
був у Дніпропетровській окрузі - 94 \% від загалу, а найнижчим у Мелітопільській - $55 \%$. Найвищою частка російськомовного населення була у Мелітопільській окрузі - 29,7 \%, тоді як у решті восьми округах вона не становила й чверті населення.

Таблиця 5

Сільське населення Східної України за рідною мовою по округах (\%)

\begin{tabular}{|c|l|c|c|c|c|}
\hline \multirow{2}{*}{ № } & \multirow{2}{*}{ Округа } & \multicolumn{4}{|c|}{ Рідна мова } \\
\cline { 3 - 6 } & & українська & російська & інші & не зазначена \\
\hline 1 & Дніпропетровська & 94 & 4,8 & 1 & 0,2 \\
\hline 2 & Криворізька & 89 & 6,2 & 4,5 & 0,3 \\
\hline 3 & Першомайська & 89 & 3 & 7,8 & 0,2 \\
\hline 4 & Зінов’ївська & 85,4 & 10 & 4,3 & 0,3 \\
\hline 5 & Запорізька & 83 & 11 & 5,5 & 0,5 \\
\hline 6 & Херсонська & 77 & 15,4 & 7,5 & 0,1 \\
\hline 7 & Миколаївська & 65 & 19,8 & 15 & 0,2 \\
\hline 8 & Одеська & 60,6 & 13 & 26 & 0,4 \\
\hline 9 & Мелітопільська & 55 & 29,7 & 15 & 0,3 \\
\hline & Разом & 79 & 12 & 8,6 & 0,4 \\
\hline
\end{tabular}

Таким чином, у 1926 р. для абсолютної більшості населення Південної України рідною мовою була українська. За своєю демографічною потужністю вона більш ніж утричі перевищувала російську мову, яку визнали рідною менше чверті населення регіону. Щодо мов інших народів, то вони посідали незначне місце в мовному середовищі Південної України. Аналіз мовної структури населення окремих округ півдня України показав, що у більшості з них абсолютну більшість становило населення, рідною мовою якого була українська. Виняток становила Одеська округа, де відносну більшість становило російськомовне населення.

Порівняння етнічної та мовної структури населення регіону дозволило зробити висновок про деформованість мовної ситуації в регіоні, про що свідчить розбіжність між рідною мовою та етнічною приналежністю частини населення. Відсоток тих, хто визнав російську мову рідною, у півтора раза перевищував частку етнічних росіян, що мешкали в Південній Україні. Серед російськомовного населення росіяни становили трохи більше половини, а решта - представники інших національностей, в тому числі й найбільшої - української, тоді як частка не українців серед україномовної спільноти регіону була незначною. Це свідчить також про те, що, попри значну демографічну потужність, українська мова мала незначний асиміляційний потенціал, поступаючись у цьому російській. Більше того, українці самі були об’'єктом асиміляції.

Більшість україномовного та іномовного населення зосереджувалася у сільській місцевості, тоді як носії російської мови були розподілені між містом та селом більш збалансовано, хоча і з перевагою у бік першого. Це також обмежува- 
ло асиміляційний потенціал української мови, оскільки сільські жителі відрізнялися значно вищою мовною стійкістю, ніж міські. Проте не це було вирішальним чинником. Асиметричний характер асиміляційних процесів у регіоні пояснюється значно більшою комунікативною потужністю російської мови, обумовленою iii фактичним статусом державної мови в СРСР, що робило іiі більш привабливою для представників етнічних меншин, ніж українську. Крім того, зазначений статус російської мови та її широке використання в усіх сферах життя як регіону, так і республіки взагалі, призводили до того, що прибульці з інших регіонів СРСР не вважали за потрібне вивчати українську мову. Росіяни демонстрували високу мовну стійкість, зберігаючи власну мову незалежно від того, де вони мешкали - у місті чи на селі. Українці ж краще зберігали рідну мову в сільській місцевості, тоді як у містах більше чверті українців визнали своєю рідною мовою російську. Особливо швидко асиміляційні процеси відбувалися у великих містах. Зокрема в Миколаєві, Одесі, Херсоні частка російськомовного населення була найвищою. Лише трохи більш ніж половина українців, що мешкали у великих містах, визнали рідною мовою українську, тоді як для решти рідною вже була російська. Мовна ситуація на селі не була настільки деформованою, як у міських поселеннях Південної України, оскільки розбіжність між рідною мовою та етнічною приналежністю частини населення була значно меншою.

Асиміляційні процеси в Південній Україні відбувалися швидше, ніж загалом по республіці. Питома вага російськомовного населення серед мешканців Південної України була майже в півтора раза більшою, ніж загалом по УСРР, а частка україномовного населення лише утричі перевищувала частку російськомовного, тоді як загалом по УСРР - у п'ять разів. В містах Південної України росіяни становили абсолютну більшість, тоді як загалом по республіці - відносну. Навіть на селі частка україномовного населення у Південній Україні була меншою, ніж загалом по УСРР, і відповідно більшою була питома вага російськомовного населення.

У перспективі планується дослідження особливостей мовної ситуації, що склалася в Південно-Східній Україні у другій половині 20-х-30-ті pp. ХХ ст.

\section{Abstract}

The author has analyzed the composition of the Southern Ukraine population on its native language, examined the peculiarities of the linguistic structure of the population in some districts as well as urban and rural settlements in the region; carried out the comparative analysis of the ethnic and linguistic structures of the population, determined the level and nature of language assimilation processes in the region and in the Ukrainian SSR in general.

The results of the study suggest that in 1926 the vast majority of the population of Southern Ukraine considered Ukrainian language as its mother tongue. The analysis of the linguistic structure of the population of some districts in Southern Ukraine showed that the Ukrainian language 
prevailed in most of them, except for Odessa district. Russian language, which less than a quarter of the population acknowledged as their native language, was the second demographic capacity language in the region. However, it had more communicative power and, as a result, more assimilation potential than Ukrainian language. This was also determined by the fact that Russian language was the official language of the USSR. The languages of other peoples living on the territory of the region generally played a minor role in its linguistic environment.

The comparative analyses of ethnic and linguistic structure of the population of Southern Ukraine showed that the Ukrainians, notwithstanding their numerical majority, have implemented insignificant assimilative influence on other ethnic communities of the region. Moreover, they themselves have suffered assimilation from the Russian ethnic minority. All the above mentioned allowed to make the conclusion about the asymmetric and unnatural character of the assimilation processes in the region. The Russian assimilative influence manifested itself mostly in urban settlements - administrative, economic and cultural centres of the South of Ukraine. In small towns and rural settlements, the process of Russian assimilation happened slower and for majority of population Ukrainian language was the mother tongue.

However, in general, the Russification on the South of Ukraine in 1926 did not acquire threatening character and for the vast majority of population the native language was the language of its nationality, the assimilation processes in the region happened more intensively than in the Ukrainian SSR in the whole.

Key words: Ukrainian language, Russian language, language assimilation, linguistic structure, ethnic structure, Southern Ukraine, All-Union Census of 1926.

\section{ДЖЕРЕЛА ТА ЛІТЕРАТУРА}

1. Воробьев Н. Всесоюзная перепись населения 17 декабря 1926 года. Краткий обзор организации и производства. Москва: В/О «Союзоргучет» редакционно-издательское управление, 1933. 103 с.

2. Воронко О. Г. Розвиток етнодемографічних процесів і формуваня соціальної структури суспільства в Україні 20-х рр. ХХ ст.: дис. ... канд. іст. наук: 07.00.05. Київ, 1998. 230 с.

3. Всесоюзний перепис людності 1926 р.: Українська соціялістична радянська республіка. Степ. Дніпрянський промисловий підрайон. Гірничий підрайон. Національність, рідна мова, вік, письменність. Т. ХІІІ, від. 1. Москва: Видання ЦСУ Союзу РСР, 1929. 465 с.

4. Гринь Д. Зміни в національному складі міського населення України у 20 30-х рр. ХХ ст. Україна на порозі ХХІ століття: актуальні питання історї: Збірник наукових праць. Київ: Стилос, 1999. С. 196-202.

5. Малярчук Н. Г. Особливості мовної ситуації в Донбасі в 20-ті pp. ХХ ст. Історичні і політологічні дослідження. 2009. № 2. С. 93-99.

6. Малярчук Н. Г. Мовна структура населення Східної України (за матеріалами Всесоюзного перепису населення 1926 року ). Нові сторінки історії Донбаcy: Збірник статей. Кн. 27. Вінниця: ДонНУ ім. Василя Стуса, 2018. С. 61-73.

7. Малярчук Н. Г. Російське населення Східної України (за матеріалами Всесоюзного перепису населення 1926 року). Історичні $і$ політологічні дослідження. 2017. № 1 (60). С. 36-44. 
8. Малярчук Н. Г. Росіяни в етнічній структурі населення південно-східної України (за матеріалами Всесоюзного перепису населення 1926 року). Нові сторінки історії Донбасу: Збірник статей. Кн. 26. Вінниця: ДонНУ імені Василя Стуса, 2017. С. 155-167.

9. Малярчук Н. Г. Українське та російське населення південної України: кількісний аспект (за матеріалами всесоюзного перепису населення 1926 року). «Science progress in European countries: new concepts and modern solutions»: Papers of the 9th International Scientific Conference. September 6, 2019, Stuttgart, Germany. P. 229-236.

10. Романцов В. О. Українці на одвічних землях (XVIII - поч. XXI ст.). Київ: Видавництво ім. Олени Теліги, 2004. 183 с.

11. Статистика України. № 124. Серія І. Демографія. Короткі підсумки перепису населення України. 12-17 грудня 1926 р. Національний і віковий склад, рідна мова та писемність населення. Харків, 1928. 210 с. Т. V. Вип. 2. Х с.

12. Турченко Г. Ф., Овчаренко Г. Ф. Етнічний склад міського населення Півдня України (за матеріалами Всесоюзного перепису населення 1926 р.). Наукові праці історичного факультету Запорізького національного університету. 2009. Вип. XXVII. С. 185-192.

\section{References}

1. Vorobev, N. (1933). Vsesoiuznaia perepis naseleniia 17 dekabria 1926 goda. Kratkii obzor organizatcii i proizvodstva [All-Union Census of December 17, 1926. Brief overview of organization and production]. Moskva: V/O «Soiuzorguchet» redaktcionno-izdatelskoe upravlenie, 103.

2. Voronko, O. H. (1998). Rozvytok etnodemohrafichnykh protsesiv i formuvania sotsialnoi struktury suspilstva v Ukraini 20-kh rr. XX st. [The Development of ethnic and demographic processes and forces of social structure in Ukraine of 20's. XX century] (Dis. ... Cand. Sc. (History). Kyiv.

3. Vsesoiuznyi perepys liudnosti 1926 r.: Ukrainska sotsiialistychna radianska respublika. Step. Dniprianskyi promyslovyi pidraion. Hirnychyi pidraion. Natsionalnist, ridna mova, vik, pysmennist (Vol. 13) [All-Soviet Union population census of 1926 Ukrainian Soviet Socialist Republic. Steppe. Dnipryans 'kyi industrial subregion. Mountain subregion. Nationality, mother tongue, age, literacy].(1929). Moskva: Vydannia TsSU Soiuzu RSR.

4. Hryn, D. (1999). Zminy v natsionalnomu skladi miskoho naselennia Ukrainy u 20-30-kh rr. XX st. [Changes in the ethnic composition of the urban population of Ukraine in the 20-30's XX century]. Ukraina na porozi XXI stolittia: aktualni pytannia istorii: Zbirnyk naukovykh prats. Kyiv: Stylos, 196-202. 
5. Maliarchuk, N. H. (2009). Osoblyvosti movnoi sytuatsii v Donbasi v 20-ti rr. XX st. [Features of the Language Situation in the Donbass in the 1920's]. Istorychni i politolohichni doslidzhennia, no. 2, 93-99.

6. Maliarchuk, N. H. (2018). Movna struktura naselennia Skhidnoi Ukrainy (za materialamy Vsesoiuznoho perepysu naselennia 1926 roku) [Language structure of the population of eastern Ukraine (based on All-Soviet Union census materials of 1926)]. Novi storinky istorii Donbasu: Zbirnyk statei. Kn. 27. Vinnytsia: DonNU im. Vasylia Stusa, 61-73.

7. Maliarchuk, N. H. (2017). Rosiiske naselennia Skhidnoi Ukrainy (za materialamy Vsesoiuznoho perepysu naselennia 1926 roku) [Russian population of Eastern Ukraine (based on All-Soviet Union census materials of 1926)]. Istorychni i politolohichni doslidzhennia, no. 1 (60), 36-44.

8. Maliarchuk, N. H. (2017). Rosiiany v etnichnii strukturi naselennia pivdennoskhidnoi Ukrainy (za materialamy Vsesoiuznoho perepysu naselennia $1926 \mathrm{roku}$ ) [The Russians in the ethnic population structure of the South-Eastern Ukraine (based on All-Soviet Union census materials of 1926)]. Novi storinky istorii Donbasu: Zbirnyk statei. Kn. 26. Vinnytsia: DonNU imeni Vasylia Stusa, 155-167.

9. Maliarchuk, N. H. (2019). Ukrainske ta rosiiske naselennia pivdennoi Ukrainy: kilkisnyi aspekt (za materialamy vsesoiuznoho perepysu naselennia 1926 roku) [Ukrainian and Russian Population of Southern Ukraine: Quantitative Aspect based on All-Soviet Union census materials of 1926)]. «Science progress in European countries: new concepts and modern solutions»: Papers of the 9th International Scientific Conference. September 6, Stuttgart, Germany, 229-236.

10. Romantsov, V. O. (2004). Ukraintsi na odvichnykh zemliakh (XVIII - poch. XXI st.) [Ukrainians on the Eternal Lands (18th-early 21st centuries)]. Kyiv: Vydavnytstvo im. Oleny Telihy, 183.

11. Statystyka Ukrainy (1928). Seriia I. Demohrafiia. Korotki pidsumky perepysu naselennia Ukrainy. 12-17 hrudnia 1926 r. Natsionalnyi i vikovyi sklad, ridna mova ta pysemnist naselennia. Kharkiv, no. 124, T. V. Vyp. 2.

12. Turchenko, H. F., Ovcharenko, D. V. (2009). Etnichnyi sklad miskoho naselennia Pivdnia Ukrainy (za materialamy Vsesoiuznoho perepysu naselennia 1926 r.) [The ethnic composition of the urban population of South Ukraine (based on the AllUnion census in 1926)]. Naukovi pratsi istorychnoho fakultetu Zaporizkoho natsionalnoho universytetu, XXVII, 185-192. 